\title{
The Canadian Field-Naturalist Online
}

\section{Online publication: A natural progression for The Canadian Field-Naturalist}

Without dismissing potential limitations, the benefits and opportunities of electronic publication are numerous. For The Canadian Field-Naturalist, these are focussed within three main areas, as summarized below.

\section{Online Content}

Scientific journals have embraced digital dissemination of information. Among peer-reviewed biology journals, $77 \%$ are published online, and this number is growing annually (UlrichsWeb 2011). As the content of scientific journals has become available online, researchers' reading habits have changed (Rowlands 2007). Academic researchers now read more articles from more journals than previously (Ollé and Borrego 2010), get most of the articles they read from the Internet (Tenopir et al. 2009), and overwhelmingly prefer online over printed journals (De Groote and Dorsch 2003). Providing content online, while continuing printed issue publication, is expected to increase access to The Canadian Field-Naturalist among researchers. By offering current issues online, The Canadian Field-Naturalist is joining the major natural history journals with North American content that are offering such services.

Providing online content should particularly increase readership of The Canadian Field-Naturalist among young researchers. While contemporary researchers tend to rely more on online journals than print, this is especially true of young researchers (Tenopir et al. 2009). Thus, if natural history research is to reach young scientists, that research needs to be available online.

Online publication facilitates three actions beyond increased content availability: searching, authorship analysis, and rapid awareness of new issue publication. First, searching for articles via Google Scholar and other public search engines is now a common way for researchers and the public to find research articles. An analysis of The Canadian Field-Naturalist website revealed many visitors were directed to our site by Google searches for words in article titles, keywords, or author names. Users can also search for content within the website, which can be more efficient than browsing printed volume indices. Second, authorship analysis is a good way to discover trends in a journal, and such analyses are easier to conduct with digitized journals than print journals because authorship information is already stored in "metadata" associated with each article. Third, readers are now able to register to receive tables of contents by e-mail whenever a new issue of The Canadian Field-Naturalist is published. Such online services enable researchers to stay abreast of current literature (Ollé and Borrego 2010).

\section{Online Manuscript Management}

While online journal content affects readers, online manuscript management affects authors, editors, and reviewers. In recent years, manuscripts submitted to The Canadian Field-Naturalist have been sent between authors, editors, and reviewers by e-mail, or occasionally by postal mail. This system involved timeconsuming work on the part of the editor tracking correspondence. Our new online manuscript management system should improve transparency and efficiency. Authors will submit their manuscript on the journal website and can then track its progress as it is assigned to associate editors and reviewers. Reviewers are automatically reminded of manuscripts they agreed to review if they take longer than the agreed-upon time. Surveys of authors, editors, and reviewers indicate that the majority of people in all three roles prefer online manuscript management systems to e-mail systems (Ware 2005). After incorporating manuscript management systems, journals tend to experience $30 \%$ faster manuscript processing (i.e., reviews, revisions, etc.), and $25 \%$ higher volume of submissions (Ware 2005). Our editors and reviewers will experience a learning curve as they get accustomed to this new system, but we anticipate it will result in faster, more efficient publication of The Canadian Field-Naturalist.

Faster publication is important for two reasons. First, most ecologists consider manuscript processing time when deciding to which journal they should submit their manuscript (Aarssen et al. 2008). Second, given that some articles in The Canadian Field-Naturalist have implications for conservation management policies, prompt publication of such articles reduces the risk of delays in conservation policy action (O'Donnell et al. 2010).

\section{Supplementary Files}

There are severe limitations to including lengthy supporting data in traditional publications due to the high cost of the additional pages. With electronic publication, however, material that is related to an article but not essential to its message can be published as supplementary files available on the journal website. For example, an article may present statistical summaries of findings, and the raw data file could be included as a supplementary file. Authors will soon 
have the option of including supplementary files in The Canadian Field-Naturalist.

Over the past 132 years The Canadian FieldNaturalist and its predecessors have adapted in response to the needs of those particular times. The changes outlined above will respond to the needs of today's authors and will bring The Canadian FieldNaturalist to more people more quickly than previously possible. We also recognize that many readers still appreciate printed copies of The Canadian FieldNaturalist. Moreover, maintaining printed copies of the journal safeguards the archives of this very important component of Canadian heritage. We are therefore pleased to continue to provide the printed version of The Canadian Field-Naturalist.

JAY M. FITZSIMMONS

Journal Manager, The Canadian Field-Naturalist

\section{Documents Cited}

UlrichsWeb. www.ulrichsweb.com. Data accessed March 8 2011.

\section{Literature Cited}

Aarssen, L. W., T. Tregenza, A. E. Budden, C. J. Lortie, J. Koricheva, and R. Leimu. 2008. Bang for your buck: rejection rates and impact factors in ecological journals. Open Ecology Journal 1: 14-19.

De Groote, S. L., and J. L. Dorsch. 2003. Measuring use patterns of online journals and databases. Journal of the Medical Library Association 91: 231-240.

O'Donnell, R. P., S. R. Supp, and S. M. Cobbold. 2010. Hindrance of conservation biology by delays in the submission of manuscripts. Conservation Biology 24: 615620.

Ollé, C., and Á. Borrego. 2010. A qualitative study of the impact of electronic journals on scholarly information behavior. Library and Information Science Research 32: 221-228.

Rowlands, I. 2007. Electronic journals and user behavior: a review of recent research. Library and Information Science Research 29: 369-396.

Tenopir, C., D. W. King, J. Spencer, and L. Wu. 2009. Variations in article seeking and reading patterns of academics: what makes a difference? Library and Information Science Research 31: 139-148.

Ware, M. 2005. Online submission and peer-review systems. Learned Publishing 18: 245-250. 